\title{
Quality of services in Health care exploring new opportunity as Medical Tourism in India
}

\author{
Aseervatham Achary, Amit Kumar Pandey, Suneel Mago, Rajaram, Sanjay Saproo, Rahul \\ Gupta
}

\begin{abstract}
Medical tourism is being a hot cake for the people of India. An emerging destination for tourism, and support getting from government is fortified the impact of services in this sector. This study is exploring the impacts of quality and cost based services in health care which is helping the health care sector to attract more customers across the world. Now a day India has been developed as a great destination for eco-tourism, medical tourism where uses of technology enabled services in medical procedure make it more safe and reliable. In this study data was normally distributed so researchers compare the mean and used $t$-test analysis. Resultants are exploratory in nature
\end{abstract}

Index terms: Medical tourism cost of services, quality of services, patients care and Health care.

\section{INTRODUCTION}

Medical Tourism sounds enigmatic being equally popular among Tourism and Hospitality industry. Graburn, (1977) studied this as a relaxation motion, snags of mundane daily life without responsibilities and obliges being pleasure, to get regular treatments at a quality hospitals. These are two opposite spheres, tourism correlated with inclination for fun $n$ frolics, freedom and treatment in hospitals with constrains of medical dilemma and sufferings, individuals avoids visiting hospitals unless a necessity is not avoidable profoundly. Ross (2001) stated that attar of hospitality and antiseptic smell of hospitals are vary of each other, Carrera \& Lunt (2010) studied medical tourism has incentivize health tourism as an favorable opportunity.

Advancement of technology in recent past and open the flood gates for medical consultancy over continents, telemedicine, medical record, and laboratory examination are few newer opportunities which are now outsourced to economic point of view to countries like India and China, India, Korea and other low cost nations. Global customers are availing these services because advancement in Knowledge in the society paves the states to vie on global stage, and hospitals run on the style of corporates are fetching their services to global customers. Alternate medical opportunities in India like Ayurveda, Panchakarma Therapy, Yoga, Aroma therapy, Rejuvenation,

Revised Manuscript Received on October 25, 2019.

Aseervatham Achary, research Scholar, Amity Business

School, Amity University, Noida.

Dr.Amit Kumar Pandey, Assistant Professor, , Amity Business

School, Amity University, Noida.

Dr. Suneel Mago, Legal Consultant, New DelhiRajaram, research

Scholar, Amity Business , School, Amity University, Noida.

Dr. Sanjay Saproo, (CEO, Hamilton Medical AG,

Switzerland)

Dr. Rahul Gupta, (Assistant Professor, Amity Business

School, Amity University Noida)
Unani, Siddha and homeopathy, Acupuncture, Naturopathy, Herbal Oil massage are antediluvian approaches of treatment here from ancient ages and Indian National capital is well-known regional medical destination for congress of surgeons and physicians. Wynne (2004) have studied that outcome for heath allied amenities and schism of healthcare amenities for economic, geographical, and social relegation has increased in mounting treatment cost and exploitation of needy.

\section{REVIEW OF LITERATURE}

Whittaker (2008) and Connell (2006) stated that growth of facilities has given rise to various tourists as an industry and also for better medical treatments few examples are bio medical tourism, education tourism, religious tourism, rural tourism where services like medical spa, and other traditional services could be available, and other therapies are considered as health tourism. Various advanced facilities like Healing invention and diagnostics, subordinate administrations clinic development, pharmaceuticals assembling, Affordable air fares, advancement in the internet coactivity's, newer channels of communication, hi-tech super specialty medical facilities at affordable fees spawn sizable revenues through patients and their family who come for availing medical facility as well as visit places of eminence. V.C.S., Kucukusta, D., Song, H. (2010) have studies many research articles and stated that FDI worth US \$ 100 million is availed by doctors and hospital management services.

Home affair Ministery has supported these activates through Medical Visa, which is a new category visa for the foreign tourist coming to our country for medical treatments and leisure activities. Medical patients do not come alone, their relatives accompany them for therapeutic treatments and leisure activities and an opportunity gets them entitled for MX Visa. These people need to get themselves registered with ministry offices. They could generally get visas in lieu of their valid passport and nature of the ailments.

Foreign therapeutic specialists from various nations like New Zealand, United Kingdom, USA, Canada and Australia are allowed to give their services at Local medical facilities in India vide 2007 notification by Ministry of Health and Family Welfare. This initiative by government is trusted upon information partaking and upgrading abilities. 


\section{Quality of services in Health care exploring new opportunity as Medical Tourism in India}

Places like Pondicherry a Union territory, Rishikesh in state of Uttrakand are popularized as wellbeing focused in providing physically recuperating, rationally reviving and profoundly advancing places for foreigners.

Mutchnick et al., 2005, Leigh Turner 2007, Carrera \& Lunt 2010, MHTC 2012, have studied that countries like Poland and Hungry in Europe, Mexico, Costa Rica Brazil in South America, Cyprus and Malta in Mediterranean, Singapore, Thailand and Malaysia evolve with multibillion dollar trade. Newman 2006 states that India Inc. receives most of their medial tourist from Asian nations

Erik Cohen (2010) found that, "three types of medical tourists, first is a Mere Tourist, second is a Medicated Tourist, one who receives is treated medically while on vacation, and third on Medical Tourist Proper, visiting for both tourism and medical treatment, and increasingly growing the supply and demand for medical tourism industry."

Ehrbeck et al. (2008) found that better and faster services and high quality attract more medical tourist then lower price, he tries to differentiate them inn five segments. A good 40 percent are found of technological advancements, 32 percent expects that their treatment will be better than their home country, 15 percent believes that they have access to faster Medicare for cardiac and orthopedic emergencies, and 9 percent expect lower fees for flexible procedure like liposuction, breast augmentation and reduction.

Bookman \& Bookman (2007) have studied the impact of health and tourism industry on global economy is substantial and long lasting. Gupta (2004) said medical tourism is cost effective and liked by patients and their family. Connell (2006) studied that this is a cultural shift in the choice and preferences for selecting destination for leisure activities, when there is a choice among non-medical treatment destination and medical treatment like surgeries, dental and other treatment destination with culturally rich societies and heritage places, people prefer to choose these destinations over others.

Crooks et al. (2011) studied facilities for medical treatments, travel destinations and eternities at countries offering medical tourism. L. Turner, (2008) Connell (2006), said medical tourists prefer to seek treatments for operations for cosmetics, dental care, IVF etc. Heung et al. (2010) have also found that as many countries are offering these services and competing among themselves for quality, price attractiveness for packages. Jagyasi (2010a, 2010b) studies that medical tourists are looking for attractiveness in hospitality travel eternities along with their medical treatments.

Heung (2010) studied that if one wishes to fully exploit true potential of this segment of industry then a coordinated efforts among hospitals, travel intermediaries and patients with their family is mandatory. Klenosky \& Gitelson (1998), said although the success of these medical tourism is depends on the efforts of these service providers, but with the advent of internet services these medical travelers may help themselves in order to search seek and finalize their travel eternity and choose best available options for their treatments.
Budeanu (2005) found that worldwide various agencies are offering their services some of them are as follows Global Choice Mad Retreat, HealthCare, Plant Hospital, Malaysian MediTravel and Co.

Budeanu (2005) found that the services of these providers are getting popularized as travelers are in the scarcity of time and coupled with the hassles of modern times. Gan and Frederick (2011) said that along with providing customer satisfaction these service providers also add value in their pre and post travel plans as in these services require special procedural arrangements for taking care in transferring medical records, post and pre care treatments. Laws (2000) said these amenities are added as information is available through internet.

Ytterhus (2000) said the way medical tourism is evolving these are very stressful and the way information flow from tourist to services provides and back is also inadequate.

Budeanu (2005) said that all this service provides act as pull strategy in achieving growth of medical tourism. Welford et al. (1999) said their influence on these tourists is vital and helps is sustaining responsible behavior and their actions as stakeholders which leads in sustainability of this industry.

Ryan C. (2015) studied that research in these area have become popular these days, the research is also influenced by available software and other facilities and it is also influenced by globalization and rise in Asian tourism industry.

Document M. et al. found that economic literature has enough contribution in this area. Research related to micro economics like demand and supply modeling, market analysis, determinants of price productivity and efficiency enquiry, game theory application in market edifice are limited, it also creates a void in terms of cooperative, empathic and competitive behavior.

Mohammed I. (2015), Guillet B.D., studied varied topics in medical tourism and tried to structure them into seven themes, hospitality being a core activity. Chrisryan, Jingjing Yanga (2016) said that in area like Xinjiang China multi-ethnic communities are residing where exploration of operational mechanism for impersonation changes in daily life of the residents which are culturally marginalized and their involvement in attraction of tourism as an industry is evolved. Yap et al. (2008) tried to differentiate procedural complexities in ailment treatments; Ho \& Wu (1999) said that satisfactions of customers are utmost importance of the success of any organization. Alam \& Yasin (2010), Kang (2006) stated that repeat purchase is an example for customer satisfaction as service provider has exceeded their perceptions. This is a situation where customers are self-driven for imminent demands and service quality plays a vital role in this process. Ajzen \& Fishnein (1977) have studied the service quality and constructive correlation amongst behavior resolved. 
Chen (2008), Chen and Chen (2011) said in this and situational intentions to contributing factor of interaction which intent as studied by Akbar \& Parvez, 2012, Olorunniwo et al. 2006).

Scant Heung (2010) explored in there study and suggested medical tourism which are moderately affecting the procedure of medical tourism in Southeast Asian continents. A broad perspective is being discussed by different parties at different stage of its evolution. Taleghani (2011) focuses on importance of medical tourism under the umbrella of different psychological aspects like experiencing the services provided by different hospitals and care givers. Behavior and attitude (Hudson \& Li 2012) of the staff nurses, cooperation of the management of the hospitals and intention of the top management is really crucial in contemporary situation. Competitive brand image perspectives are defined in a different way to explore the initial aspects of services. Wu (2011), Kim et al. 2008 describe about the strategic implications of the market positions and brand image to retain the lose positioning of the foundation of marketing.

Zineldin (2006) mentioned that getting good services by the hospitals should be ethical obligation for every party. Debono and Travagila (2009) describe in their research that desired expectation from the patients and influence of the patient satisfaction judges by the different parties to explore required nature of the patients return activities. Analysis of the strengths and weakness of the hospitals define the trade belief of all the parties. Getting back to lose patients from the respective hospitals is always depends on services quality rendered by the hospitals. Satisfaction and benefits are two different aspect to understand the required services.

\begin{tabular}{|c|c|c|c|c|c|}
\hline Procedure & USA & India & Thailand & Malaysia & Korea \\
\hline pass & \begin{tabular}{|l|} 
Rs. \\
1080000
\end{tabular} & $\begin{array}{l}\text { Rs. } \\
364000\end{array}$ & \begin{tabular}{|l|} 
Rs. \\
1058470
\end{tabular} & 0100 & \begin{tabular}{|l|} 
Rs. \\
2023000
\end{tabular} \\
\hline $\begin{array}{l}\text { Hip } \\
\text { Replacement }\end{array}$ & \begin{tabular}{|l|} 
Rs. \\
350000
\end{tabular} & $\begin{array}{l}\text { Rs. } \\
49000\end{array}$ & \begin{tabular}{|l} 
Rs. \\
552530
\end{tabular} & Rs. 800100 & Rs. 988400 \\
\hline $\begin{array}{l}\text { Knee } \\
\text { replacement }\end{array}$ & $\begin{array}{l}\text { Rs. } \\
350000\end{array}$ & $\begin{array}{l}\text { Rs. } \\
43400\end{array}$ & $\begin{array}{l}\text { Rs. } \\
860790\end{array}$ & 000 & Rs. 138600 \\
\hline $\begin{array}{l}\text { Breast } \\
\text { Implants }\end{array}$ & \begin{tabular}{|l|} 
Rs. \\
700000
\end{tabular} & $\begin{array}{l}\text { Rs. } \\
245000\end{array}$ & \begin{tabular}{|l|} 
Rs. \\
190890
\end{tabular} & $\mathrm{R}$ & 0890 \\
\hline Hysterectomy & $\begin{array}{l}\text { Rs. } \\
10500\end{array}$ & $\begin{array}{l}\text { Rs. } \\
175000\end{array}$ & $\begin{array}{l}\text { Rs. } \\
190890\end{array}$ & Rs. 367500 & Rs. 77000 \\
\hline Liposuction & $\begin{array}{l}\text { Rs. } \\
63000\end{array}$ & $\begin{array}{l}\text { Rs. } \\
196000\end{array}$ & $\begin{array}{l}\text { Rs. } \\
196000\end{array}$ & Rs. 160930 & $\mathrm{~N} / \mathrm{A}$ \\
\hline $\begin{array}{ll}\text { Lasik } & \text { (Both } \\
\text { Eyes) } & \end{array}$ & $\begin{array}{l}\text { Rs. } \\
30800\end{array}$ & $\begin{array}{l}\text { Rs. } \\
3500\end{array}$ & $\begin{array}{l}\text { Rs. } \\
127260\end{array}$ & Rs. 33390 & Rs. 42000 \\
\hline Tummy Tuck & $\begin{array}{l}\text { Rs. } \\
682500\end{array}$ & $\begin{array}{l}\text { RS. } \\
21000\end{array}$ & $\begin{array}{l}\text { Rs. } \\
35000\end{array}$ & $\begin{array}{l}\text { Data } \\
\text { unavailable }\end{array}$ & $\begin{array}{l}\text { Data } \\
\text { unavailable }\end{array}$ \\
\hline Lift of face & $\begin{array}{l}\text { Rs. } \\
105000\end{array}$ & RS. & 28000 & Rs. 35000 & \begin{tabular}{|l|} 
Rs. \\
1071000
\end{tabular} \\
\hline
\end{tabular}

\section{Purpose of the study.}

Health care is being the fundamental right of the common people. For medical tourism, people from across the word attracted for their personal needs. Enjoyment with treatment is prime focus of the people coming from outside the country and key accelerator of medical tourism in India. Spirituality management is being the beauty of this country where traditional medicine is found in bulk. Since ancient time, world always look towards India for their medicinal requirement. In mythological stories, lots of incidents have been discussed with proper evidences in which patients has been cured with naturopathy and traditional medicine. India is in que of world class medical facilities where experts from different domain are working progressively for the common cause. Specialized medical centers to world class surgical equipment, modified and well versed therapeutic facilities are the beauty of this fraternity. From Middle East, a chunk of patients are coming for Cosmetics surgery, Dental procedures, Heart Surgeries, coronary bypass, heart checkups, replacement of valves Knee surgery and Eye surgeries. Apart from that Ayurveda treatment is also contributing their best for the tourist and now a day it has become the center of attraction for foreigners in India.

\section{Study objectives:}

Main objectives of the analysis is moving around the explore the implication and emergence of medical tourism in India. Especially in SAARC countries India is emerging as hot cake for medical tourism and especially patients of south East Asian continents who are not able to effort the procedural cost in their respective country. In last decades, number of hospitals has been opened in India for better services in health care and quality of services available in these hospitals which are serving not only Indian patients, even patients from abroad are also visiting India for economical and best services. Following objectives are created for the further study.

- To explore the impact of cost effective services on Indian medical tourism.

- To analyze impact of quality services in emerging medical tourism era.

\section{Methodology used in this study:}

It is an exploration based study where various aspect of medical tourism has been studies according to the demand of the objectives. The major focuses have been concentrated on quality of services which is the beauty of the services sector in India. Quality services always attracted the people from outside the word to come to India for their health related issues. Since the cost of services are really economical in comparison with other countries. This study is a primary data based analysis. Schedule as a tool of data collection 300 samples has been collected from different Corporate and government hospitals. Data has collected from Delhi and NCR's hospitals like Fortis, Max, Apollo and Medanta.

\section{Hypothesis for the study:}

Hypothesis formulation in the study has been done on the basis of the variables explored from the literature review. Hypothesis has been proposed on the basis of the objectives framed in the study because normally hypothesis known as key assumption for the problems. 
Few issues proposed on the basis of research design made for this study. Since a sound hypothesis always leads towards a appropriate solution, it has been taken care to make hypothesis testable with the help of the sound statistical interventions. According to (Brandit and Binder, 2006) Hypothesis requires more exploration on the basis of proposed assumptions in any study. Exemplary design research has been proposed by the (Brandit and Binder, 2007) which proposed relationship among all the proposed variables in this study. They explored with the literature review that procreative approach can not revealed the situation according to the demand of the problem.

\section{Hypothesis formulation and testing}

Hypothesis 1. Cost effective medical services are attracting medical tourism in India.

H0: There is no significant relationship between cost effective services and attractive medical tourism in India.

H1: There is no significant relationship between cost effective services and attractive medical tourism in India.

Cost effective medical services are attracting medical tourism in India. Against the hypothesis set for the study data has been collected and put on SPSS for the further analysis. After applying t-test, it has been analyzed that calculated value of alpha in significant two tailed test is 0.0023 which is less than the standard value.

Thus in this hypothesis testing researchers is fail to accept the null hypothesis.

Table -2 Sample correlation (Paired)

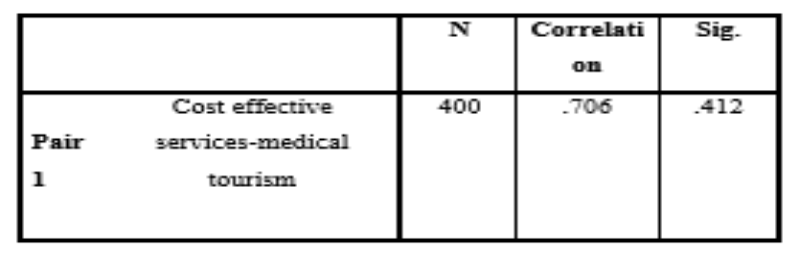

Table -3, Sample statistics (Paired)

\begin{tabular}{|c|c|c|c|c|}
\hline & Mean & $\mathbf{N}$ & $\begin{array}{c}\text { Std. } \\
\text { Deviatio } \\
\mathbf{n}\end{array}$ & $\begin{array}{c}\text { Std. } \\
\text { Error } \\
\text { Mean }\end{array}$ \\
\hline \begin{tabular}{|cc} 
& Cost effective \\
Pai & services-medical \\
r 1 & tourism
\end{tabular} & $\begin{array}{c}0.024 \\
75 \\
\\
0.321 \\
87\end{array}$ & $\begin{array}{l}500 \\
500\end{array}$ & $\begin{array}{l}.21432 \\
.14235\end{array}$ & $\begin{array}{l}.032145 \\
.032456\end{array}$ \\
\hline
\end{tabular}

Table -4, Paired Differences

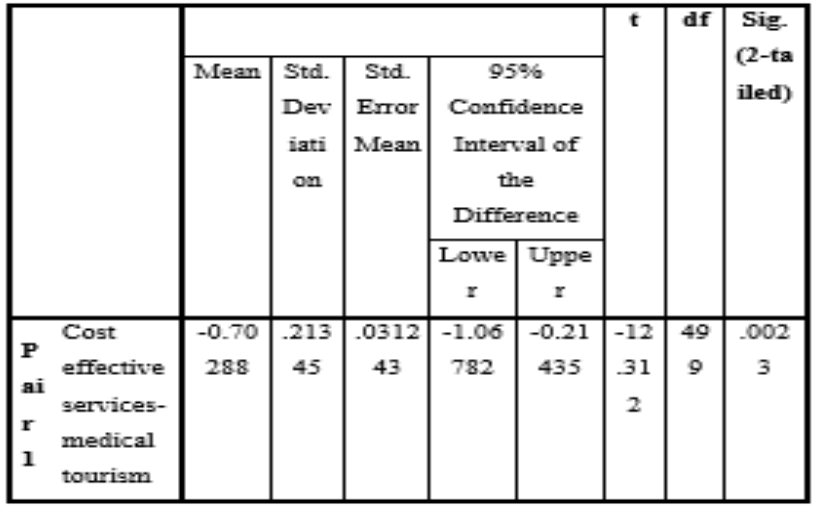

Hypothesis 2. In Indian subcontinent emergence of technology enabled, quality based services are key focus area for improvement in medical tourism.

H0: There are no significant relation between Quality services and medical tourism.

H1: There are significant relation between Quality services and medical tourism.

\section{Table -5, Paired Samples Correlations}

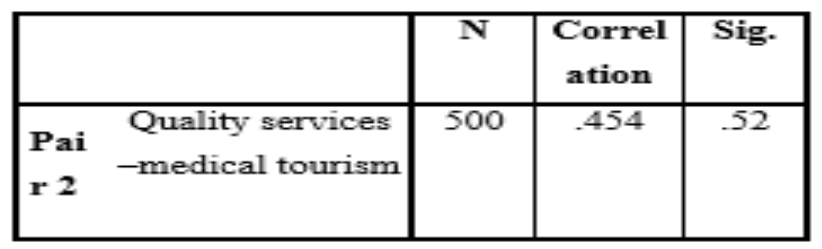

\section{Table-6, Paired Samples Statistics}

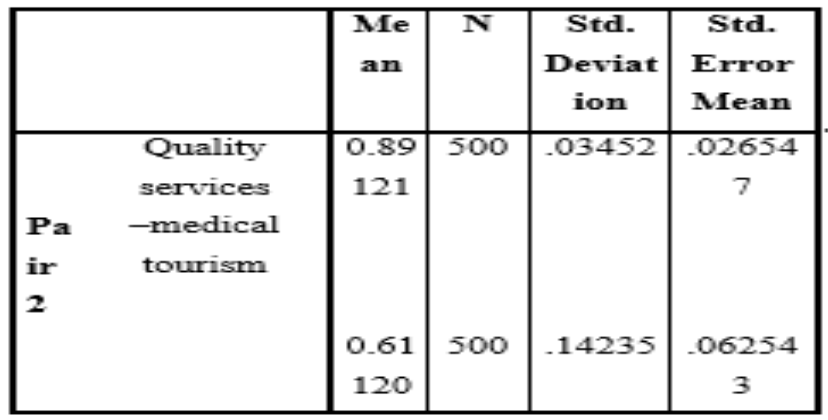

Table-7, Paired Samples Test

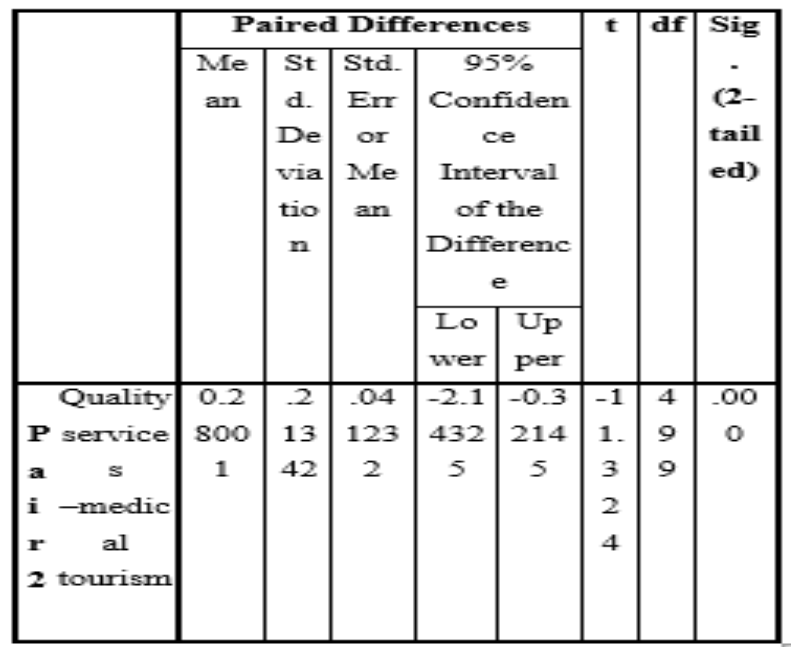


Hypothesis proposed for the study, In Indian subcontinent emergence of technology enabled, quality based services are key focus area for the development of medical tourism. Against the Hypothesis calculated value of the p 0.000 which is less than the standard value. Hence researchers fail to accept the null hypothesis.

\section{ReSUltants:}

In recent decades, there are various policies implemented by the corporate and government authorities to fueled medical tourism in country. Across the world, image of India has been drastically changes and now India has been treated as most important nation in terms of their technology based services. It has become a multibillion dollar industry which is protected and nurtured by the recent government.

In hypothesis testing few factors has been explored after the extensive data analysis that there are significant relationship between quality services and medical tourism in India. In first hypothesis researchers is failing to accept the null hypothesis. On another hand, in second hypothesis once again researchers are not succeeded to accept the null hypothesis, which means alternate hypothesis in the study is getting accepted. Thus researchers are reaching on the conclusion that there are significant relation between Quality services and medical tourism.

\section{CONCLUSION}

Elite group who travelled outside the country for medical services are now staying in the country for the treatment. Private hospital in India is influx of patients from Afghanistan and Gulf countries. Apart from this region, even numbers of patients from united states of America are also seeking treatment from India due to cost factors. Hypothesis in the study is also focusing on the same issues. Aging patients from Canada and United Kingdom which public funded health insurance is unable to cope up with the rising demands also like this country as a new destination of medical tourism.

\section{Limitation of the Study:}

Study is moving around the medical tourism and quality based services in health care industry. Health care industry always given an opportunity to emerging India where factors like quality, cost effective services, error free environment and insurance enabled patient protection is being the prime concern for the patients. In this study medical insurance and patient safety has not been covered which will be the part of next study. Time and resources were main constraints not to cover these aspects in this study.

\section{REFERENCES}

1. Ajzen, I., \& Fishbein, M. (1977). Attitude-behavior relations: A theoretical analysis and review of empirical research. Psychological bulletin, 84(5), 888-918.

2. Akbar, M. M., \& Parvez, N. (2009). Impact of service quality, trust, and customer satisfaction on customers loyalty. ABAC Journal, 29(1)., $24-38$.

3. Aldaqal, S., Alghamdi, H., AlTurki, H., Eldeek, S., \& Kensarah, A. (2012). Determinants of patient satisfaction in the surgical ward at a University Hospital in Saudi Arabia. Life Science Journal, 9(1), 277-280
4. Bookman, M.Z., \& Bookman, K.R. (2007). Medical Tourism in Developing Countries. New York: Palgrave Macmillan.

5. Budeanu, A. (2005). Impacts and responsibilities for sustainable tourism: a tour operator perspective. Journal of Cleaner Production, 13(2), 89-97.

6. Carrera, P., \& Lunt, N. (2010). A European perspective on medical tourism: the need for a knowledge base. International Journal Of Health Services, 40(3), 469-484.

7. Chen, C. F. (2008). Investigating structural relationships between service quality, perceived value, satisfaction, and behavioral intentions for air passengers: Evidence from Taiwan. Transportation Research Part A: Policy and Practice, 42(4), 709-717.

8. Cohen, E. (2010). Medical tourism- A critical evaluation. Tourism Recreation Research, 35 (3), 225-238.

9. Connell, J. (2006). Medical tourism: Sea, sun, sun and .surgery. Tourism Management, 27, 1093-1100.

10. Crooks, V.A., Turner, L., Snyder, J., Johnston, R., \& Kingsbury, P. (2011). Promoting medical tourism to India: messages, images, and the marketing of international patient travel.

11. Debono D. \& Travaglia J. (2009). Complaints and patient satisfaction: a comprehensive review of the literature. Centre for Clinica Governance Research, University of New South Wales, Sydney, Australia.

12. Document M., I., Denizci G., B., Law, R. (2015) The contributions of economics to hospitality literature: A content analysis of hospitality and tourism journals, International Journal of Hospitality Management, 44, pp. 99-110

13. Ehrbeck, T., Guevara, C., \& Mango, P. D. (2008, May). Mapping the market for medical travel. The McKinsey Quarterly Magazine.

14. Gan, L.L., \& Frederick, J.R. (2011). Medical tourism facilitators Patterns of service differentiation. Journal of Vacation Marketing, 17(3), 165-183.

15. Graburn, N. H. (1977). Tourism: The sacred journey. In V. L. Smith, Hosts and Guests (pp. 17-31). Philadelphia: University of Pennsylvania Press.

16. Guillet, B.D., Mohammed, I. (2015). "Document Revenue management research in hospitality and tourism: A critical review of current literature and suggestions for future research", International Journal of Contemporary Hospitality Management, 27 (4), pp. 526-560.

17. Gupta, H.D. (2004). Medical tourism and public health. Peoples Democracy. 27(19)

18. Henry Tsai, Steve Pan, Jinsoo Lee, (2011) "Recent research in hospitality financial management", International Journal of Contemporary Hospitality Management, Vol. 23 Iss: 7, pp. 941 - 971

19. Heung, V.C.S., Kucukusta, D., \& Song, H. (2010). A Conceptual Model of Medical Tourism: Implications for Future Research. Journal of Travel \& Tourism Marketing, 27(3), 236-251,

20. Ho, C. F., \& Wu, W. H. (1999). Antecedents of Customer Satisfaction on the Internet: An Empirical Study of Online Shopping. Proceedings of the 32nd Hawaii International Conference on System Sciences. Hawaii, USA.

21. Heung, V.C.S., Kucukusta, D., \& Song, H. (2010). A Conceptual Model of Medical Tourism: Implications for Future Research. Journal of Travel \& Tourism Marketing, 27(3), 236-251, doi:10.1080/10548401003744677.

22. 22.Hudson, S., \& Li, X. (2012). Domestic medical tourism: A neglected dimension of medical tourism research. Journal of Hospitality Marketing \& Management, 21(3), 227-246.

23. Jingjing Yanga, Chrisryan, (2016). Impersonation in ethnic tourism The presentation of culture by other ethnic groups. Annals of Tourism Research, 16-31.

24. Kang, G.-D. (2006). The hierarchical structure of service quality: integration of technical and functional quality. Managing Service Quality, 16 (1), 37-50.

25. Klenosky, D.B., \& Gitelson, R.E. (1998). Travel agent

26. destination recommendations. Annals of Tourism Research, 25(3), 661-674.

27. Kim, K. H., Kim, K. S., Kim, D. Y., Kim, J. H., \&

28. Kang, S. H. (2008). Brand equity in hospital Journal of business research, 61(1), 75-82

29. Kirsner, R. S., \& Federman, D. G. (1997). Patient satisfaction: quality of care from the patients' perspective. Archives of dermatology, 133(11), 1427-1431

\section{Published By:}

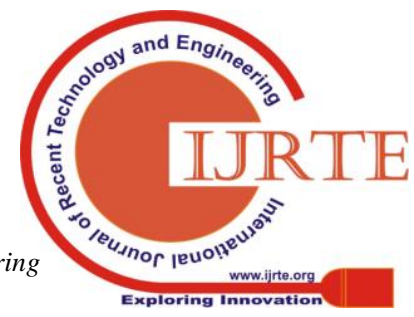


30. Laws, E. (2000). Service quality in tourism research: Are we walking tall (yet)? Journal of Quality Assurance in Hospitality and Tourism, 1(1), 31-56.

31. Lin, H. C. (2014). Assessment of the Partnership Quality between Travel Agencies and Health Care Organizations on the International Medical Tourism Market in Taiwan. Journal of QualityAssurance in Hospitality \& Tourism, 15(4), 356-381

32. 30.Mohamad, W. N., Omar, A., \& Haron, M. S. (2012). The moderating effect of medical travel facilitators in medical tourism. Procedia-Social and Behavioral Sciences, 65, 358-363.

33. 31. Mutchnick, I., Stern, D., \& Moyer, C. (2005). Trading health services across borders: GATS, markets, and caveats. Health Affairs, W5, $42-51$

34. 32. Newman, Byron Y (2006): "Medical Tourism", Journal of American Optometric Association, 77(12): 581.

35. 33. Olorunniwo, F., Hsu, M. K., \& Udo, G. J. (2006). Service quality, customer satisfaction, and behavioral intentions in the service factory. Journal of Services Marketing, 20(1), 59-72.

36. 34. Ryan, C. (2015). "Trends in hospitality management research: A personal reflection" International Journal of Contemporary Hospitality Management 27 (3), pp. 340-361

37. 35. Ross. (2001, September 6). Medical check-ups on the run. Bangkok Post, Horrizons, p. 3.

38. 36. Taleghani, M., Largani, M. S., \& Mousavian, S. J. (2011). The role of health tourism in development process (concepts and applications). Australian Journal of Basic and Applied Sciences, 5(10), 544-550.

39. 37. Turner, L. (2007). First World Health Care at Third World Prices: Globalization, Bioethics and Medical Tourism. Bio Societies, 2(3), 303-325, doi: 10.1017/s1745855207005765.

40. 38. Welford, R., Ytterhus, B., \& Eligh, J. (1999). Tourism and sustainable development: an analysis of policy and guidelines for managing provision and consumption. Sustainable Development, 7, 165.

41. 39. Whittaker, A (2008): "Pleasure and Pain: Medical Travel in Asia", Global Public Health, 3 (3): 271-90.

42. 40. Wu, C.C. (2011). The impact of hospital brand image

43. on service quality, patient satisfaction and loyalty.

44. African Journal of Business Management, 5(12),

45. 4873-4882.

46. 41. Wynne, J Michael (2004): "Hazards in the Corporatisation of Health Care", New Doctor, 80 (Autumn): 2-5.

47. 42. Yap, J., Chen, S. S., \& Nones, N. (2008). Medical tourism: The Asian chapter. Singapore: Deloitte.

48. 43. Zineldin, M. (2006). The quality of health care and patient satisfaction: an exploratory investigation of the

49. 5Qs model at some Egyptian and Jordanian medical

50. clinics. International Journal of Health Care Quality Assurance, 19(1), 60-92.

\section{AUTHORS PROFILE}

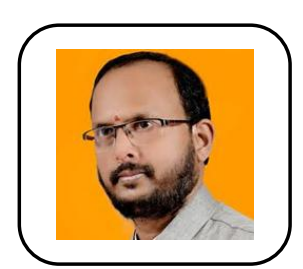

Asservatham Achary is senior bureacrates (VRS)and research scholar at Amity Business School, Amity University Noida.

aseer1969achary@gmail.com

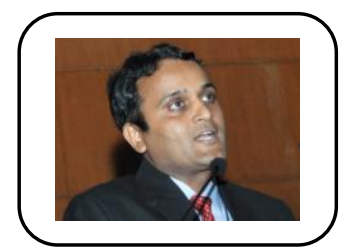

Dr Amit Kumar Pandey is having profound experience of 18 years in Research, Corporate, Academics, Training and Development. Dr. Pandey has more than 50 research papers in referred National and International journals and 40 research paper presented by Dr. Pandey in national and International conferences. Apart from that he is regular contributor in various Hindi and English newspaper and Magazine. amitkbp@gmail.com

\section{Dr. Suneel Mago,}

Rajaram (Research Scholar, Amity Business School, Amity University Noida)

Dr. Sanjay Saproo, (CEO, Hamilton Medical AG, Switzerland)

Dr. Rahul Gupta (Assistant Professor, Amity Business School, Amity University Noida) 